\title{
Przesłanki pozytywne umorzenia należności z tytułu składek na ubezpieczenie społeczne
}

\section{Positive Prerequisites for the Use of Reliefs in the Payment of Dues on Social Insurance Contributions}

Streszczenie. Dopuszczalne jest stosowanie ulg w zapłacie składek na ubezpieczenie społeczne, które polegają albo na definitywnej rezygnacji wierzyciela z całości lub odpowiedniej części należnej kwoty (umorzenie częściowe lub całkowite), albo jedynie na czasowej rezygnacji z takich kwot (odroczenie terminu zapłaty lub rozłożenie płatności na raty). Zastosowanie takich ulg możliwe jest po zaistnieniu przesłanek określonych w ustawie, np. w przypadku całkowitej nieściągalności składek, ze względów gospodarczych lub innych przyczyn zasługujących na uwzględnienie w przypadkach uzasadnionych ważnym interesem zainteresowanego. Wyżej wymienione przesłanki mają charakter klauzul generalnych, pozwalających na ich elastyczne dostosowanie do konkretnych sytuacji. Podmioty uprawnione do udzielania ulg w zapłacie składek na ubezpieczenie społeczne działają w granicach uznania administracyjnego. Nie jest to jednak działanie w pełni swobodne, ponieważ skutki ekonomiczne wynikające z zastosowania takich ulg mają bezpośredni wpływ na stan równowagi finansowej fun- 
duszy celowych, z których finansowane są świadczenia z tytułu ubezpieczenia społecznego, w szczególności emerytury, renty oraz zasiłki.

Słowa kluczowe: składka na ubezpieczenie społeczne; ulga; umorzenie; odroczenie terminu płatności; rozłożenie płatności na raty.

\begin{abstract}
It is permissible to use reliefs in the payment of social security contributions, based either on a definitive waiver by the creditor of the whole or relevant part of the amount due (partial or complete remission) or only a temporary waiver of such amounts (payment deferral or payment in installments). The use of such reliefs is possible upon the occurrence of conditions laid down in the Act, for example, in the case of total non-recovery of contributions, for economic or other reasons worth considering, if justified by important interests of the person concerned. The prerequisites mentioned above have a nature of general clauses, allowing for their flexible adjustment to specific situations. Entities authorized to grant reliefs in the payment of social security contributions act within the limits of administrative discretion. But it is not a fully free operation, because the economic impact resulting from the use of such reliefs has a direct impact on the financial balance of earmarked funds which finance social security benefits, in particular pensions, disability allowances and other benefits.
\end{abstract}

Keywords: social insurance contributions; relief; remission; payment deferral; payment in installments.

\title{
1. Uwagi wprowadzające
}

Składki na ubezpieczenie społeczne są formą daniny publicznej. Stanowi o tym art. 5 ust. 2 pkt 1 ustawy z dnia 27 sierpnia 2009 r. o finansach publicznych $^{1}$. Obowiązek ich ponoszenia na rzecz wyodrębnionych państwowych funduszy celowych wynika z postanowień odrębnych ustaw ${ }^{2}$. Ze względu na częściową zależność wysokości świadczeń z ubezpieczenia

Tekst jedn. Dz.U. z 2013 r., poz. 885 ze zm.

2 Np. ustawa z dnia 13 października 1998 r. o systemie ubezpieczeń społecznych (tekst jedn. Dz.U. z 2013 r., poz. 1442 ze zm., dalej: u.s.u.s.); ustawa z dnia 20 grudnia 1990 r. o ubezpieczeniu społecznym rolników (tekst jedn. Dz.U. z 2013 r., poz. 1403 ze zm., dalej: u.u.s.r.); art. 42 ustawy z dnia 12 marca 2004 r. o pomocy społecznej (tekst jedn. Dz.U. z 2013 r., poz. 182 ze zm.); art. 51 ustawy z dnia 4 lutego 2011 r. o opiece nad dziećmi w wieku do lat 3 (tekst jedn. Dz.U. z 2013 r., poz. 1457). 
społecznego od wysokości wnoszonej składki można w niej dostrzegać formę odpłatności i zwrotności, co odróżnia niniejsze składki od podatków, które są podstawową formą daniny publicznej ${ }^{3}$.

Standardy ustanawiania oraz stosowania danin publicznych określają przede wszystkim art. 84 oraz art. 217 Konstytucji Rzeczypospolitej Polskiej$^{4}$. W rozumieniu przepisów Konstytucji RP daniną publiczną jest świadczenie pieniężne pobierane na rzecz podmiotów publicznych ${ }^{5}$, którego ustanowienie, przynajmniej częściowo, służy gromadzeniu środków potrzebnych na realizację przez państwo celów (zadań) publicznych. Z cytowanych przepisów konstytucyjnych wywodzone są gwarancje, zgodnie z którymi określona kategoria daniny publicznej będzie wprowadzana nie tylko w celu zgromadzenia środków niezbędnych do sfinansowania zadań publicznych, ale również z zachowaniem równowagi między rosnącymi w rozwijającym się państwie potrzebami publicznymi a prawami majątkowymi i osobistymi indywidualnego podmiotu ponoszącego ciężar takiej daniny ${ }^{6}$.

Zasady przyznawania ulg i umorzeń dotyczących danej kategorii daniny publicznej według art. 217 Konstytucji RP powinny być ustalone w ustawie. Zgodnie z zasadą określoności powyższe zasady powinny być uregulowane w akcie rangi ustawowej w sposób bardzo precyzyjny, przejrzysty i jasny ${ }^{7}$. W pełni można zaakceptować pogląd, że w konstytucyjnym pojęciu „umorzeń”, użytym w art. 217 Konstytucji RP, powinny

3 E. Ruśkowski, Komentarz do art. 5 [w:] E. Ruśkowski, J.M. Salachna (red.), Finanse publiczne. Komentarz praktyczny, Gdańsk 2013, s. 69.

4 Konstytucja Rzeczypospolitej Polskiej z dnia 2 kwietnia 1997 r. (Dz.U. Nr 78, poz. 483 ze zm.).

5 A. Bień-Kacała, Daniny publiczne. Próba rekonstrukcji pojęcia na tle postanowień Konstytucji RP z 1997 r., „Prawo i Administracja” 2003, t. 2, s. 101; A. Bień-Kacała, O definiowaniu danin publicznych raz jeszcze. Uwagi na tle wyroku Trybunału Konstytucyjnego z 19 lipca 2011 r. (P 9/09) [w:] R.M. Czarny, K. Spryszak (red.), Państwo i prawo wobec współczesnych wyzwań, t. 3, Zagadnienia prawa konstytucyjnego. Księga jubileuszowa Profesora Jerzego Jaskierni, Toruń 2012, s. 520.

6 M. Bartoszewicz, J. Zakolska, Glosa do wyroku SO we Wrocławiu z 20.05.2003 r., IV Ka 893/02, „Przegląd Legislacyjny” 2003, nr 5, s. 117; A. Krzywoń, Podatki i inne daniny publiczne - podstawowe pojęcia konstytucyjne, „Zeszyty Naukowe Sądownictwa Administracyjnego" 2011, nr 2, s. 57.

7 Wyrok NSA z dnia 12 listopada 2010 r., I FSK 1957/09, LEX nr 744502. 
zawierać się wszystkie systemowe formy dobrowolnej rezygnacji wierzyciela daniny publicznej z całości lub części przysługującego mu świadczenia $^{8}$. Niniejsza rezygnacja może być definitywna (umorzenie częściowe lub całkowite) albo jedynie czasowa (odroczenie terminu zapłaty lub rozłożenie płatności na raty). Wszystkie wyżej wymienione rodzaje ulg w zapłacie składek na ubezpieczenie społeczne mogą być stosowane na podstawie art. 41a u.u.s.r. oraz art. 28 i art. 29 u.s.u.s.

Analogiczne rodzaje ulg możliwe są do zastosowania w odniesieniu do podatków oraz innych danin publicznych, do których stosuje się przepisy Ustawy z dnia 29 sierpnia 1997 r. - Ordynacja podatkowa9 . Są to tzw. ulgi w spłacie zobowiązań podatkowych udzielane na etapie stosowania przepisów prawa podatkowego. W Ordynacji podatkowej granice stosowania tych ulg wyznaczają pojęcia nieostre, tzn. „ważny interes podatnika” oraz „interes publiczny”. Nie istnieje zatem ściśle określony katalog przesłanek, okoliczności, zdarzeń czy też powodów (ani też z góry określona ich hierarchia), którymi należy kierować się przy rozstrzyganiu spraw podatkowych dotyczących ulg w spłacie zobowiązań podatkowych $^{10}$. Organ podatkowy może udzielać ulg w spłacie zobowiązań podatkowych, a więc decyzje podejmowane są w ramach tzw. uznania administracyjnego. Nawet w sytuacji zaistnienia okoliczności wskazujących na istnienie chociażby jednej $\mathrm{z}$ wyżej wymienionych przesłanek, organ podatkowy nie jest bezwzględnie zobowiązany do zastosowania ulgi w spłacie zobowiązania podatkowego. Rozstrzygnięcie organu nie może mieć jednak charakteru dowolnego, lecz powinno być wynikiem wyjaśnienia stanu faktycznego sprawy, wszechstronnego zebrania oraz rozpatrzenia w sposób wyczerpujący materiału dowodowego ${ }^{11}$.

Ulgą w zapłacie należności z tytułu składek na ubezpieczenie społeczne o najbardziej doniosłych skutkach prawnych oraz ekonomicznofinansowych jest ich umorzenie w części lub w całości. Poniżej poddano

$8 \quad$ K. Koperkiewicz-Mordel, Stanowienie przez rady gmin zwolnień i ulg podatkowych w podatkach i opłatach lokalnych, „Finanse Komunalne” 2005, nr 1-2, s. 59.

Tekst jedn. Dz.U. z 2012 r., poz. 749 ze zm.

Wyrok NSA z dnia 23 kwietnia 2013 r., II FSK 1813/11, LEX nr 1336963.

Wyrok WSA w Kielcach z dnia 28 listopada 2013 r., I SA/Ke 422/13, LEX nr 1426494. 
analizie materiał normatywny, dorobek orzeczniczy sądów administracyjnych oraz wybrane poglądy przedstawicieli doktryny w zakresie przesłanek dopuszczających umorzenie takich należności.

\section{Możliwość umorzenia należności z tytułu składek ubezpieczeniowych wymierzanych na podstawie przepisów ustawy o systemie ubezpieczeń społecznych}

W przepisach u.s.u.s. oraz u.u.s.r. odmiennie sformułowano przesłanki, których zaistnienie pozwala na umorzenie należności z tytułu składek na ubezpieczenie społeczne. Stosownie do postanowień art. 24 ust. 2 u.s.u.s. ustawowy zwrot „należności z tytułu składek” jest kategorią obejmującą składki na ubezpieczenie społeczne, a także odsetki za zwłokę, koszty egzekucyjne, koszty upomnienia i dodatkową opłatę wymierzaną przez Zakład Ubezpieczeń Społecznych płatnikowi składek w razie ich nieopłacenia lub opłacenia ich w zaniżonej wysokości (do wysokości 100\% nieopłaconych składek). Zgodnie z art. 28 u.s.u.s. prawo umarzania w całości lub w części należności z tytułu składek na ubezpieczenie społeczne przysługuje ZUS. Niniejszego przepisu nie stosuje się do składek finansowanych przez ubezpieczonych niebędących płatnikami składek, co wprost wynika z postanowień art. 30 u.s.u.s. ${ }^{12}$

Główną przesłanką uzasadniającą zastosowanie ulgi w zapłacie składek w formie umorzenia składek jest całkowita ich nieściągalność, jednak niniejsza przesłanka nie ma charakteru bezwzględnie wiążącego. W art. 28 ust. 3a u.s.u.s. dopuszczono bowiem możliwość umarzania takich należności także w przypadkach braku ich całkowitej nieściągalności.

Przypadki „całkowitej nieściągalności składek” wyliczono w art. 28 ust. 3 u.s.u.s. w sposób wyczerpujący. W każdym z nich można wskazać wyraźne motywy ekonomiczne uzasadniające umorzenie składek i zaniechanie $\mathrm{w}$ ten sposób prowadzenia dalszego postępowania zmierzającego

12 Wyrok NSA z dnia 25 października 2012 r., II GSK 1520/11, LEX nr 1404591; wyrok WSA w Olsztynie z dnia 30 września 2010 r., I SA/OI 118/10, LEX nr 749519. 
do wyegzekwowania obowiązku ich zapłaty, które mogłoby prowadzić jedynie do podwyższania kosztów postępowania finansowanych ze środków publicznych. Zaistnienie co najmniej jednej z przesłanek wymienionych w art. 28 ust. 3 u.s.u.s. pozwala już na stwierdzenie całkowitej nieściągalności składek. Niniejsze przesłanki należy bowiem traktować rozłącznie. Spośród siedmiu przypadków uzasadniających umorzenie składek z powodu ich całkowitej nieściągalności, aż pięć nawiązuje do bezskuteczności lub braku możliwości egzekucji. Są to następujące przesłanki:

a. brak majątku pozostałego po śmierci dłużnika lub pozostawienie ruchomości niepodlegających egzekucji ${ }^{13}$ albo pozostawienie przedmiotów codziennego użytku domowego, których łączna wartość nie przekracza kwoty stanowiącej trzykrotność przeciętnego wynagrodzenia i jednoczesny brak następców prawnych oraz brak możliwości przeniesienia odpowiedzialności na osoby trzecie,

b. zaprzestanie prowadzenia działalności przy jednoczesnym braku majątku, z którego można egzekwować należności, małżonka, następców prawnych, możliwości przeniesienia odpowiedzialności na osoby trzecie w rozumieniu przepisów Ordynacji podatkowej (okoliczności uzasadniające umorzenie należności nie mogą mieć charakteru przemijającego, a jednocześnie powinny wskazywać na brak majątku, z którego można byłoby zaspokoić dochodzoną należność; dlatego też zawieszenie działalności gospodarczej, które nie ma definitywnego charakteru, nie może być traktowane na równi z przesłanką wymienioną $\mathrm{w}$ art. 28 ust. 3 pkt 3 u.s.u.s. ${ }^{14}$ ),

13 Np. przedmioty urządzenia domowego, pościel, bielizna i ubranie niezbędne dla zobowiązanego i będących na jego utrzymaniu członków rodziny, a także ubranie niezbędne do pełnienia służby lub wykonywania zawodu; narzędzia i inne przedmioty niezbędne do pracy zarobkowej wykonywanej osobiście przez zobowiązanego, z wyłączeniem środka transportu, oraz surowce niezbędne do tej pracy na okres $7 \mathrm{dni}$; przedmioty niezbędne do pełnienia służby przez zobowiązanego lub do wykonywania przez niego zawodu - por. art. 8 ustawy z dnia 17 czerwca 1966 r. o postępowaniu egzekucyjnym w administracji (tekst jedn. Dz.U. z 2012 r., poz. 1015 ze zm.).

Wyrok NSA z dnia 30 stycznia 2013 r., II GSK 2005/11, LEX nr 1298463. 
c. niska kwota nieopłaconej składki (która nie przekracza kwoty kosztów upomnienia w postępowaniu egzekucyjnym ${ }^{15}$ ),

d. stwierdzenie przez naczelnika urzędu skarbowego lub komornika sądowego braku majątku, z którego można prowadzić egzekucję,

e. oczywiste stwierdzenie, że w postępowaniu egzekucyjnym nie uzyska się kwot przekraczających wydatki egzekucyjne.

$\mathrm{Z}$ powyższego wyliczenia oraz sposobu sformułowania przesłanek wynika, że powoływanie się przez organ jedynie na fakt wszczęcia postępowania egzekucyjnego jest absolutnie niewystarczające do wykazania, że nie występuje całkowita nieściągalność należności, o której mowa w art. 28 u.s.u.s. ${ }^{16}$ Postępowanie egzekucyjne, które nadal jest w toku, wyłącza zaistnienie przesłanki całkowitej nieściągalności należności z tytułu składek. Dopóki postępowanie to jest w toku, nie można bowiem definitywnie stwierdzić bezskuteczności egzekucji ${ }^{17}$.

Pozostałe przesłanki, umożliwiające przyjęcie wniosku o całkowitej nieściągalności należności z tytułu składek ubezpieczeniowych, są następujące:

- oddalenie przez sąd wniosku o ogłoszenie upadłości dłużnika lub umorzenie postępowania upadłościowego, bowiem majątek niewypłacalnego dłużnika nie wystarcza na zaspokojenie kosztów postępowania (na postanowienie o oddaleniu wniosku o ogłoszenie upadłości z uwagi na fakt, że majątek dłużnika nie wystarcza na zaspokojenie kosztów postępowania, nie można powoływać się w nieograniczonym czasie $\mathrm{w}$ postępowaniu o umorzenie należności z tytułu składek na ubezpieczenie społeczne, tym bardziej w sytuacji, gdy przedsiębiorstwo nadal funkcjonuje, zatrudnia pracowników i zawie-

15 Koszty upomnienia wynoszą czterokrotną wartość opłaty dodatkowej pobieranej przez Pocztę Polską za polecenie przesyłki listowej - por. rozporządzenie Ministra Finansów z dnia 27 listopada 2001 r. w sprawie wysokości kosztów upomnienia skierowanego przez wierzyciela do zobowiązanego przed wszczęciem egzekucji administracyjnej (Dz.U. Nr 137, poz. 1543).

16 Wyrok WSA w Opolu z dnia 18 stycznia 2012 r., I SA/Op 503/11, LEX nr 1109650; wyrok WSA w Warszawie z dnia 13 lutego 2008 r., V SA/Wa 2573/07, LEX nr 501337.

17 Wyrok WSA w Warszawie z dnia 15 grudnia 2009 r., V SA/Wa 969/09, LEX nr 583522. 
ra nowe kontrakty; przesłanka do umorzenia zaległości powinna zaistnieć bowiem w okresie bezpośrednio związanym z wydaniem decyzji ${ }^{18}$ ), - brak zaspokojenia należności w zakończonym postępowaniu likwidacyjnym (wykreślenie wpisu do ewidencji działalności gospodarczej, w przypadku zawiadomienia o zaprzestaniu wykonywania działalności gospodarczej, nie jest zakończeniem postępowania likwidacyjnego w rozumieniu art. 28 ust. 3 pkt 4 u.s.u.s. ${ }^{19}$ ).

Wyjątek dopuszczający możliwość umorzenia należności z tytułu składek na ubezpieczenie społeczne pomimo braku przesłanki całkowitej ich nieściągalności ma ustawowo wyznaczone granice podmiotowe, ponieważ możliwy jest do zastosowania tylko w odniesieniu do ubezpieczonych będących równocześnie płatnikami składek na ubezpieczenie społeczne. Niniejszy przepis obejmuje zatem tylko należności przysługujące ZUS od płatnika z tytułu jego ubezpieczenia, a nie ubezpieczenia pracowników ${ }^{20}$. Tryb umorzenia określony w art. 28 ust. 3a u.s.u.s. może być zastosowany na wniosek złożony przez zobowiązanego ${ }^{21}$. Granice przedmiotowe wyjątku wynikającego z postanowień art. 28 ust. 3a u.s.u.s. zostały natomiast wytyczone zbyt ogólnie, ponieważ umorzenie składek może następować „w uzasadnionych przypadkach”.

Nie sformułowano w ustawie żadnych kryteriów (np. ekonomicznych, społecznych), według których można byłoby kwalifikować określone przypadki do kategorii „uzasadnione przypadki”. Niedookreślone w jakimkolwiek przepisie ustawy pojęcie „uzasadniony przypadek” nie pozwala jednak na zupełną dowolność sposobu rozstrzygnięcia sprawy dotyczącej umorzenia składek na ubezpieczenie społeczne ${ }^{22}$. Z dniem 2 maja 2003 r. dodano przepis art. 28 ust. 3b u.s.u.s., upoważniający ministra właściwego do spraw zabezpieczenia społecznego do określenia

18 Wyrok WSA w Warszawie z dnia 8 grudnia 2006 r., III SA/Wa 2448/06, LEX nr 328903.

19 Wyrok NSA z dnia 20 kwietnia 2011 r., II GSK 498/10, LEX nr 1081550.

20 Wyrok WSA w Bydgoszczy z dnia 8 czerwca 2011 r., I SA/Bd 239/11, LEX nr 821342; wyrok NSA z dnia 5 kwietnia 2011 r., II GSK 422/10, LEX nr 992384.

21 J. Wantoch-Rekowski, Umarzanie należności z tytułu składek na ubezpieczenia spoteczne, „Praca i Zabezpieczenie Społeczne” 2004, nr 3, s. 34.

22 Wyrok WSA w Gliwicach z dnia 26 października 2010 r., III SA/GI 1207/10, LEX nr 756448 . 
w drodze rozporządzenia szczegółowych zasady umarzania należności z tytułu składek na ubezpieczenia społeczne ubezpieczonych będących równocześnie płatnikami składek na te ubezpieczenia (w uzasadnionych przypadkach) pomimo braku ich całkowitej nieściągalności ${ }^{23}$. Zgodnie z wytycznymi ustawodawcy minister obowiązany jest uwzględniać przesłanki uzasadniające umorzenie, w tym ważny interes osoby zobowiązanej do opłacenia należności z tytułu składek oraz stan finansów ubezpieczeń społecznych.

W przepisach rozporządzenia również zastosowano przesłanki pozwalające organowi orzekającemu na dokonywanie oceny, czy dany przypadek umorzenia należności z tytułu składek na ubezpieczenie społeczne zawiera się w kategorii „uzasadnione przypadki”. Umorzenie tych należności przez ZUS będzie możliwe wtedy, gdy zobowiązany wykaże, że ze względu na stan majątkowy i sytuację rodzinną nie jest w stanie opłacić tych należności, ponieważ pociągnęłoby to zbyt ciężkie skutki dla zobowiązanego i jego rodziny, w szczególności w przypadku:

a. gdy opłacenie należności z tytułu składek pozbawiłoby zobowiązanego i jego rodzinę ${ }^{24}$ możliwości zaspokojenia niezbędnych potrzeb życiowych (w jednym z wyroków trafnie oceniono, że w sytuacji, w której miesięczny dochód rodziny z najwyższym trudem pozwala na zaspokojenie miesięcznych kosztów wyżywienia i ubrania trudno byłoby przyjąć, że umożliwia on jednocześnie opłacenie należności z tytułu zaległych składek ${ }^{25}$ ),

b. poniesienia strat materialnych w wyniku klęski żywiołowej lub innego nadzwyczajnego zdarzenia powodujących, że opłacenie należności z tytułu składek mogłoby pozbawić zobowiązanego możliwości dalszego prowadzenia pozarolniczej działalności gospodarczej,

23 Rozporządzenie Ministra Gospodarki, Pracy i Polityki Społecznej z dnia 31 lipca 2003 r. w sprawie szczegółowych zasad umarzania należności z tytułu składek na ubezpieczenia społeczne (Dz.U. Nr 141, poz. 1365).

24 Zgodnie z przepisami omawianego rozporządzenia za rodzinę uważa się wspólnie zamieszkujące i gospodarujące z zobowiązanym osoby spokrewnione lub niespokrewnione pozostające z zobowiązanym w faktycznym związku.

25 Wyrok WSA w Krakowie z dnia 29 października 2009 r., I SA/Kr 1154/09, LEX nr 573353. 
c. przewlekłej choroby zobowiązanego lub konieczności sprawowania opieki nad przewlekle chorym członkiem rodziny, pozbawiającej zobowiązanego możliwości uzyskiwania dochodu umożliwiającego opłacenie należności.

Powyższe wyliczenie jest jedynie przykładowe, co oznacza, że zamiarem prawodawcy było objęcie możliwością umorzenia należności z tytułu składek jak największej liczby przypadków, w których ze względu na stan majątkowy i sytuację rodzinną zobowiązany nie jest w stanie opłacić tych należności, ponieważ pociągnęłoby to zbyt ciężkie skutki dla zobowiązanego i jego rodziny ${ }^{26}$. Sposób sformułowania przesłanek uzasadniających zastosowanie umorzenia należności w zasadzie nie powinien budzić wątpliwości. System ubezpieczenia społecznego jest systemem ustawowo gwarantującym świadczenia związane z pracą, służące zaspokajaniu potrzeb wywołanych przez zdarzenia losowe i finansowane przez ubezpieczonych na zasadzie rozłożenia ich ciężaru na osoby do nich następnie uprawnione. Mieszcząca się w tym systemie również funkcja ochronna ubezpieczenia społecznego nie pozwala na egzekwowanie niespłaconych składek w każdej sytuacji, bez względu na konsekwencje dla zobowiązanego i jego rodziny ${ }^{27}$.

Przesłanki, które mogą podlegać ocenie przez organ orzekający, to: „stan majątkowy”, „sytuacja rodzinna”, „zbyt ciężkie skutki dla zobowiązanego i jego rodziny”. Należy jednocześnie podkreślić, że połączenie spójnikiem „,i” stanu majątkowego oraz sytuacji rodzinnej zobowiązanego prowadzi do wniosku, że obie przesłanki muszą występować łącznie, aby uzasadnione było zastosowanie ulgi w zapłacie składek w postaci częściowego lub całkowitego ich umorzenia. Z treści §3 ust. 1 cytowanego rozporządzenia wynika wprost, że na wnioskodawcy spoczywa ciężar udowodnienia okoliczności wskazujących na jego stan majątkowy i sytuację rodzinną ${ }^{28}$. Decyzja organu orzekającego ma takich przypadkach

26 Wyrok WSA w Białymstoku z dnia 4 listopada 2011 r., I SA/Bk 363/11, LEX nr 1149811; wyrok WSA w Łodzi z dnia 2 września 2010 r., I SA/Łd 715/10, LEX nr 751635.

27 Wyrok WSA w Olsztynie z dnia 1 grudnia 2010 r., I SA/OI 719/10, LEX nr 749668; wyrok NSA z dnia 21 maja 2009 r., II GSK 1045/08, LEX nr 564200. Wyrok NSA z dnia 6 czerwca 2012 r., II GSK 685/11, LEX nr 1216696. 
charakter uznaniowy. Oznacza to, że organ przy wydawaniu takiej decyzji obowiązany jest do rzetelnej i wnikliwej analizy wszelkich okoliczności sprawy w celu stwierdzenia, czy zostały spełnione określone w przepisach przesłanki. Dopiero w ten sposób przeprowadzona analiza stanu faktycznego sprawy stanowi materię będącą podstawą do wydania decyzji o charakterze uznaniowym. W sytuacji, gdy prawodawca dopuścił możliwość zastosowania umorzenia należności „w uzasadnionych przypadkach”, organ odmawiając zastosowania umorzenia, jest zobowiązany wykazać, że okoliczności konkretnej sprawy nie uzasadniają potraktowania jej w sposób szczególny ${ }^{29}$.

Pojęcie „uzasadniony przypadek” użyte w treści art. 28 ust. 3a u.s.u.s. było wielokrotnie analizowane przez sądy administracyjne. Podkreślono, że dokonując wykładni tego pojęcia, organ orzekający powinien odwołać się do obowiązującego systemu prawa, uwzględniając zasadę powszechności ponoszenia ciężarów i świadczeń publicznych zawartą w art. 84 Konstytucji RP, zgodnie z którą każdy jest obowiązany do ponoszenia ciężarów i świadczeń publicznych, w tym podatków określonych w ustawach, co ma bezpośrednie odniesienie do norm wynikających z art. 2a ust. 1, ust. 2 pkt. 2 i ust. 3 u.s.u.s. stanowiących o tym, że stoi ona na gruncie równego traktowania wszystkich ubezpieczonych bez względu na płeć, stan cywilny, stan rodzinny, a zasada równego traktowania dotyczy w szczególności obowiązku opłacania i obliczania wysokości składek na ubezpieczenie społeczne ${ }^{30}$. W pojęciu „uzasadnionych przypadków” mieści się pojęcie „ważnego interesu” strony ${ }^{31}$.

W dorobku orzeczniczym sądów administracyjnych podkreśla się, że „uzasadnione przypadki” to przypadki wyjątkowe, a nawet drastyczne, powstałe z przyczyn całkowicie obiektywnych (niezależnych od dłużnika) ${ }^{32}$. Jednocześnie wyraźnie wskazano, że cechy te muszą odnosić się do stanu majątkowego, w jakim znajduje się dłużnik, a nie tego, czy słusznie po-

\footnotetext{
Wyrok NSA z dnia 25 sierpnia 2008 r., II GSK 724/09, LEX nr 746112.

Wyrok WSA w Gliwicach z dnia 21 grudnia 2010 r., III SA/GI 1909/10, LEX nr 756675.

Wyrok NSA z dnia 15 stycznia 2008 r., II GSK 158/07, LEX nr 471124.

Uzasadnienie wyroku NSA z dnia 5 marca 2013 r., II GSK 2269/11, LEX nr 1296039; wyrok NSA z dnia 23 kwietnia 2009 r., II GSK 884/08, LEX nr 558740.
} 
wstał dług w należnościach z tytułu składek na ubezpieczenie społeczne ${ }^{33}$. Zwrot ustawowy „uzasadnione przypadki” ma charakter katalogu otwartego, ale umorzenie należności może następować tylko w sytuacjach skrajnych, takich jak: groźba pozbawienia zobowiązanego i jego rodziny możliwości zaspokojenia niezbędnych potrzeb życiowych; poniesienie strat materialnych w wyniku klęski żywiołowej lub innego nadzwyczajnego zdarzenia; przewlekła choroba zobowiązanego lub konieczność sprawowania opieki nad przewlekle chorym członkiem rodziny ${ }^{34}$.

Na podstawie art. 28 u.s.u.s. organ orzekający w sprawie może dokonać umorzenia całości lub tylko części należności z tytułu składek na ubezpieczenie społeczne. Działając w granicach uznania administracyjnego, wyznaczonych przesłankami wynikającymi z przepisów u.s.u.s. oraz cytowanego wyżej rozporządzenia Ministra Gospodarki, Pracy i Polityki Społecznej z dnia 31 lipca 2003 r., organ orzekający w konkretnej sytuacji podejmuje decyzję o umorzeniu należności w całości lub w odpowiedniej części. Prawodawca nie określa w jakiej części (minimalnej lub maksymalnej) w porównaniu do całkowitej kwoty należności można dokonać umorzenia należnych składek na ubezpieczenie społeczne. Pozostawiono zatem organowi orzekającemu stosowny „luz decyzyjny” do wykorzystywania w sytuacjach warunkowanych konkretnymi okolicznościami.

Zgodnie z art. 28 ust. 4 u.s.u.s. umorzenie składek powoduje także umorzenie odsetek za zwłokę, kosztów upomnienia i dodatkowej opłaty. Z cytowanego przepisu nie wynika jednak, czy w przypadku umorzenia części należności z tytułu składek ubezpieczeniowych w odpowiedniej proporcji należy również umorzyć odsetki za zwłokę, koszty upomnienia oraz dodatkową opłatę, czy też możliwe jest ich umorzenie w pełnej kwocie pomimo częściowego umorzenia należności z tytułu składek. Problemu tego nie można rozstrzygnąć poprzez zastosowanie art. 31 u.s.u.s., zgodnie z którym do należności z tytułu składek stosuje się odpowiednio wymienione w nim przepisy Ordynacji podatkowej, w tym art. 59 §1 pkt 8 tej ustawy. Niniejszy przepis stanowi jedynie, że zobowiązanie podatkowe wygasa w całości lub w części wskutek umorzenia zaległości. Określa

33 Wyrok WSA w Bydgoszczy z dnia 28 marca 2012 r., I SA/Bd 99/12, LEX nr 1136854. 34 Wyrok WSA w Lublinie z dnia 8 marca 2012 r., III SA/Lu 17/12, LEX nr 1139284. 
zatem skutki prawne wywołane poprzez umorzenie pełnej kwoty lub tylko części kwoty należności z tytułu składek, o którym mowa w art. 28 ust. 1 u.s.u.s. ${ }^{35}$. W art. 31 u.s.u.s. nie odesłano natomiast do art. 67a §2 Ordynacji podatkowej, zgodnie z którym umorzenie zaległości podatkowej powoduje również umorzenie odsetek za zwłokę w całości lub w takiej części, w jakiej została umorzona zaległość podatkowa.

$\mathrm{Z}$ treści art. 28 ust. 4 u.s.u.s. wynika, że nie może nastąpić umorzenie samych składek bez umorzenia należności ubocznych, ponieważ w przypadku umorzenia składek z mocy prawa nastąpi także umorzenie odsetek za zwłokę, kosztów upomnienia i opłaty dodatkowej ${ }^{36}$. Nie ma natomiast zakazu umorzenia w całości lub w części samych należności ubocznych ${ }^{37}$. Na podstawie art. 28 ust. 1 u.s.u.s. organ orzekający może umorzyć tylko część składek, co z mocy prawa powoduje umorzenie odpowiedniej części należności ubocznych (odsetek za zwłokę, kosztów upomnienia i opłaty dodatkowej) ${ }^{38}$. W tym ostatnim przypadku sąd przyjął zasadę proporcjonalnego umorzenia należności głównej (w razie zastosowania ulgi w postaci umorzenia części składek) oraz należności ubocznych, pomimo że niniejsza reguła nie została wyrażona wprost w art. 28 u.s.u.s. ani w art. 31 u.s.u.s. nie odesłano do postanowień art. 67a §2 Ordynacji podatkowej.

\section{Przesłanki dopuszczające umorzenie należności z tytułu składek na ubezpieczenie społeczne rolników}

Przesłanki umorzenia składek na ubezpieczenie społeczne rolników określono w art. 41a u.u.s.r. Na wniosek zainteresowanego decyzję o umorzeniu całości lub części należności z tytułu składek może podjąć Prezes Kasy Rolniczego Ubezpieczenia Społecznego lub upoważniony przez

\footnotetext{
Wyrok WSA w Warszawie z dnia 16 listopada 2007 r., V SA/Wa 1443/07, LEX nr 483863. Wyrok WSA w Warszawie z dnia 12 listopada 2007 r., V SA/Wa 1210/07, LEX nr 483939. Wyrok WSA w Bydgoszczy z dnia 14 września 2010 r., I SA/Bd 537/10, LEX nr 746984; wyrok WSA w Warszawie z dnia 6 października 2008 r., V SA/Wa 1444/08, LEX nr 579809.

38 Wyrok WSA w Warszawie z dnia 7 sierpnia 2008 r., V SA/Wa 1133/08, LEX nr 560184.
} 
niego pracownik ${ }^{39}$. Podobnie jak w przypadku umorzeń dokonywanych na podstawie art. 28 u.s.u.s., również w art. 41a u.u.s.r. przesłanki pozytywne umorzenia należności sformułowano elastycznie, umożliwiając $\mathrm{w}$ ten sposób organowi orzekającemu działanie w granicach uznania administracyjnego $^{40}$. Decyzje w przedmiocie ulg określonych w art. 41a u.u.s.r., jako decyzje uznaniowe, podlegają kontroli sądu administracyjnego w ograniczonym zakresie. Sąd nie może poddawać ocenie, czy dokonany przez organ administracji wybór jest słuszny, a zatem sąd nie jest uprawniony do badania merytorycznej zasadności (celowości) decyzji administracyjnej, bowiem takie rozstrzygnięcie należy wyłącznie do organów administracyjnych. Decyzja uznaniowa w pełnym zakresie podlega natomiast badaniu, co do jej zgodności z przepisami proceduralnymi, i ocenie, czy organ administracyjny prawidłowo zgromadził materiał dowodowy, czy wyciągnięte wnioski w zakresie merytorycznym decyzji o odmowie umorzenia zaległości mają swoje uzasadnienie w zebranym w sprawie materiale dowodowym, oraz czy dokonana ocena mieści się w ustawowych granicach, zaś wyciągnięte wnioski są logiczne i poprawne ${ }^{41}$.

Podstawową przesłanką dopuszczającą umorzenie jest „uzasadniony ważny interes zainteresowanego". Niniejsza przesłanka musi jednak być badana w kontekście możliwości płatniczych wnioskodawcy oraz stanu finansów funduszów emerytalno-rentowego i składkowego. Możliwości płatnicze to nie fakt osiągania dochodów, ale zestawienie tego dochodu z wydatkami, które pozwolą na ustalenie, jaki jest rzeczywisty stan finansów zainteresowanego skorzystaniem z ulgi w postaci umorzenia należności z tytułu składek ${ }^{42}$.

39 A. Jonik, Umorzenie należności z tytułu składek na ubezpieczenie społeczne rolników w świetle kodeksu postępowania administracyjnego, „Ubezpieczenia w Rolnictwie” 2007, nr 30, s. 33.

40 Wyrok NSA z dnia 21 lutego 2013 r., II GSK 2227/11, LEX nr 1311458; wyrok WSA w Rzeszowie z dnia 20 grudnia 2012 r., I SA/Rz 1060/12, LEX nr 1233588.

41 Wyrok WSA w Kielcach z dnia 29 marca 2012 r., I SA/Ke 100/12, LEX 1136977.

42 Wyrok WSA w Rzeszowie z dnia 24 kwietnia 2012 r., I SA/Rz 205/12, LEX nr 1145329. 
Uściślenia trybu postępowania w przypadku umorzenia należności na wniosek dłużnika dokonano w przepisach zarządzenia Prezesa KRUS ${ }^{43}$. Można zastosować ulgę w postaci umorzenia, gdy zachodzi co najmniej jedna z następujących przesłanek:

a. brak jest możliwości potrącenia zadłużenia ze świadczeń,

b. nie zachodzą okoliczności do orzeczenia o przeniesieniu odpowiedzialności za zobowiązania z tytułu składek,

c. z rozeznania o możliwościach płatniczych dłużnika wynika brak źródeł dochodu oraz majątku, z którego można by efektywnie dochodzić należności,

d. sytuacja finansowa zobowiązanego uniemożliwia uregulowanie całości zadłużenia nawet przy udzieleniu dogodnych ulg w spłacie,

e. opłacenie należności z tytułu składek pozbawiłoby zobowiązanego i jego rodzinę możliwości zaspokojenia niezbędnych potrzeb życiowych,

f. zobowiązany poniósł w wyniku klęski żywiołowej lub innego nadzwyczajnego zdarzenia straty materialne powodujące, że opłacanie należności z tytułu składek stanowiłoby w tej sytuacji znaczne obciążenie finansowe dla zobowiązanego i jego rodziny,

g. zaistnienie przewlekłej choroby zobowiązanego lub konieczność sprawowania przez niego opieki nad przewlekle chorym członkiem rodziny, co pozbawia zobowiązanego możliwości uzyskania dochodu umożliwiającego opłacenie należności.

Ponadto zastrzeżono, że przypadku wniosku o umorzenie składek rolnika-beneficjenta pomocy de minimis $\mathrm{w}$ rolnictwie umorzenie takie może nastąpić w sytuacji, gdy prowadzone postępowanie potwierdzi, że dłużnik ten znajduje się w przejściowo trudnej sytuacji, a udzielenie pomocy de minimis w rolnictwie nie spowoduje przekroczenia określonego pułapu pomocy. W przypadku wpływu wniosku od rolnika-beneficjenta pomocy w ramach programów pomocowych umorzenie składek w całości lub części może nastąpić na zasadach określonych w programach pomocowych.

43 Zarządzenie Prezesa KRUS z dnia 8 grudnia 2010 r. w sprawie trybu umarzania, odpisywania i udzielania ulg w spłacaniu należności z tytułu składek na ubezpieczenie społeczne rolników i na ubezpieczenie zdrowotne oraz z tytułu nienależnie pobranych świadczeń (Dz.Urz. Prezesa KRUS z 2011 r. Nr 1, poz. 31 ze zm.). 
Pojęcie „ważny interes zainteresowanego” było wielokrotnie analizowane przez sądy administracyjne. Jest to zwrot niedookreślony, który zawiera dwa odróżniające się elementy: opis faktu - „interes zainteresowanego”, który wymaga stwierdzenia, oraz element ocenny - „ważny”, wymagający oszacowania wagi stwierdzonego faktu. To, że norma prawna operuje takim zwrotem niedookreślonym, ma istotne znaczenie w procesie wykładni, gdyż organ stosujący prawo ważąc interes zainteresowanego musi dokonać oceny jednostkowej, bez - co do zasady - odwoływania się do systemu normatywnego ${ }^{44}$. Ważny interes charakteryzuje się nieprzewidywalnością i niezależnością od sposobu postępowania zobowiązanego. Występuje w sytuacjach szczególnych, w których niemożność uregulowania należności spowodowana jest przypadkami losowymi, takimi jak: klęski żywiołowe powodujące utratę majątku, trwała niezdolność zarobkowania wywołana chorobą, niepełnosprawność. Przez ważny interes zobowiązanego należy rozumieć nadzwyczajne względy, które mogłyby zachwiać podstawami jego egzystencji ${ }^{45}$. Ważnego interesu ubezpieczonego nie można zatem identyfikować wyłącznie ze zdarzeniem losowym ${ }^{46}$.

Oceniono, że niemożność zapłacenia przez ubezpieczonego składki, rozumiana jako absolutny brak środków na jej realizację bądź też jako brak środków na zapłatę bez uszczuplenia podstawowych potrzeb życiowych, przemawia za przyjęciem wystąpienia ważnego interesu ubezpieczonego $^{47}$. Ważny interes zobowiązanego zachodzi także wówczas, gdy na skutek niskich zarobków, sytuujących się na granicy minimum socjalnego, wnioskodawca nie jest w stanie pogodzić obowiązku spłaty należności z koniecznością zaspokojenia podstawowych potrzeb życiowych ${ }^{48}$. Trafnie podkreślono, że jedynie matematyczne zestawienie wydatków i dochodów nie oznacza, iż dokonano oceny możliwości płatniczych zobowiązanego. Niezbędne jest zawarcie w uzasadnieniu analizy sytuacji

\footnotetext{
Wyrok WSA w Białymstoku z dnia 13 lutego 2013 r., I SA/Bk 28/13, LEX nr 1277672.

Wyrok WSA w Kielcach z dnia 15 września 2011 r., I SA/Ke 350/11, LEX nr 966058.

Wyrok WSA w Bydgoszczy z dnia 5 lipca 2011 r., I SA/Bd 131/11, LEX nr 1083991; wyrok WSA w Kielcach z dnia 4 czerwca 2009 r., I SA/Ke 158/09, LEX nr 563360.

Wyrok WSA w Rzeszowie z dnia 25 lipca 2013 r., I SA/Rz 381/13, LEX nr 1348658.

Wyrok WSA w Rzeszowie z dnia 28 maja 2013 r., I SA/Rz 314/13, LEX nr 1325288.
} 
finansowej źródeł dochodów, wysokości świadczeń, a przede wszystkim relacji pomiędzy wydatkami koniecznymi dla egzystencji zobowiązanego i jego rodziny. Tylko taka analiza może skutkować jednoznacznym ustaleniem, jaki w rzeczywistości jest dochód zobowiązanego i czy umożliwia mu on zapłatę zaległości ${ }^{49}$.

Użyty w treści przepisu art. 41a u.u.s.r. zwrot „możliwości płatnicze wnioskodawcy” nie powinien być rozumiany jako możliwość zaspokojenia wierzytelności z tytułu nieopłaconych składek, tzn. nie jest tak, że w każdej sytuacji, gdy majątek wnioskodawcy pozwala na zaspokojenie wierzytelności, należy domniemywać istnienie po stronie wnioskodawcy możliwości płatniczych ${ }^{50}$.

Ustawowe przesłanki umorzenia należności z tytułu składek na ubezpieczenie społeczne rolników nie odnoszą się w żaden sposób do okoliczności powstania zaległości (czy powstały z winy zainteresowanego, czy też bez jego winy), lecz jedynie do oceny aktualnych (w chwili wydawania decyzji w przedmiocie umorzenia) możliwości płatniczych zainteresowanego, z uwzględnieniem elementu ochrony interesu publicznego, który wyraża się w ochronie stabilności systemu ubezpieczeń społecznych, co nakazuje egzekwowanie zaległych należności ${ }^{51}$.

Zwrócono także uwagę na fakt, że umorzenie składek na ubezpieczenie emerytalno-rentowe rolników stanowi pomoc de minimis, która ma charakter selektywny i może być przyznawana podmiotom, które znajdują się w przejściowo trudnej sytuacji i istnieje pozytywna prognoza co do dalszych wyników beneficjenta. Decyzje o ewentualnym umorzeniu zaległości nie mogą mieć charakteru powtarzającego się, wpływając na osiągnięcie pozytywnego wyniku gospodarczego ${ }^{52}$.

Ustawa o ubezpieczeniu społecznym rolników ma charakter branżowy, w odróżnieniu od ustawy o systemie ubezpieczeń społecznych, która ma charakter uniwersalny (systemowy). W związku z tym w u.u.s.r. jako

\footnotetext{
Wyrok WSA w Poznaniu z dnia 21 lutego 2013 r., III SA/Po 1286/12, LEX nr 1321009. Wyrok NSA z dnia 23 marca 2011 r., II GSK 332/10, LEX nr 1218179.

Wyrok WSA w Lublinie z dnia 16 października 2012 r., III SA/Lu 379/12, LEX nr 1234651.

52 Wyrok WSA w Białymstoku z dnia 16 stycznia 2013 r., I SA/Bk 383/12, LEX nr 1334632.
} 
jedną z przesłanek umorzenia należności z tytułu składek wymieniono stan finansów funduszów emerytalno-rentowego i składkowego. W przepisach u.s.u.s. odwołano się w tym zakresie do bardziej uniwersalnej wartości, tzn. do stanu finansów ubezpieczeń społecznych. Zgodnie z art. 76 u.u.s.r. Fundusz Składkowy Ubezpieczenia Społecznego Rolników (tzw. fundusz składkowy) oraz fundusz emerytalno-rentowy stanowią podstawy finansowe ubezpieczenia i działalności KRUS. Są to państwowe fundusze celowe.

W treści art. 41a u.u.s.r. posłużono się również pojęciem „całkowita nieściągalność należności z tytułu składek”, z tym że dotyczy to możliwości umorzenia z urzędu części lub całości takiej należności. Niniejsza kompetencja przysługuje Prezesowi KRUS lub upoważnionemu przez niego pracownikowi KRUS. Bezpośrednio w u.u.s.r. wymieniono cztery przypadki uzasadniające przyjęcie stanu „całkowitej nieściągalności należności z tytułu składek”. Niniejszy stan powstaje wtedy, gdy:

a. W wyniku postępowania egzekucyjnego lub na podstawie posiadanych dokumentów stwierdzono, że dłużnik nie posiada źródeł dochodu i majątku, z którego można dochodzić należności, oraz brak jest możliwości przeniesienia odpowiedzialności,

b. dłużnik zmarł, nie pozostawiając majątku, z którego można byłoby dochodzić należności, i jednocześnie nie ma możliwości przeniesienia odpowiedzialności,

c. kwota należności nie przekracza pięciokrotnej wartości upomnienia w postępowaniu egzekucyjnym,

d. jest oczywiste, że w postępowaniu egzekucyjnym dotyczącym należności nie uzyska się kwoty przewyższającej koszty postępowania egzekucyjnego.

Odmiennie niż w art. 28 u.s.u.s. w przepisie art. 41a u.u.s.r. wyraźnie sformułowano zasadę proporcjonalności, która powinna być stosowana w przypadku umorzenia całości lub części należności z tytułu składek ubezpieczeniowych. Zgodnie z niniejszą regułą umorzenie składek powoduje również umorzenie odsetek za zwłokę w całości lub w takiej części, w jakiej zostały umorzone składki, oraz powoduje umorzenie kosztów upomnienia należnych KRUS. 


\section{Uwagi końcowe}

Sposób uregulowania przesłanek pozytywnych umarzania należności z tytułu składek ubezpieczeniowych, polegający na zastosowaniu zwrotów niedookreślonych, umożliwia organom orzekającym podejmowanie decyzji opartych o konstrukcję uznania administracyjnego. Elastyczność działania organów orzekających, charakterystyczna dla decyzji podejmowanych w ramach uznania administracyjnego, jest pewną zaletą. Umożliwia bowiem dostosowanie ogólnych kryteriów (przesłanek) ustawowych do konkretnych przypadków. Oznacza ponadto, że organ orzekający może dokonywać wyboru rozstrzygnięcia, tzn. może, a nie jest obowiązany umorzyć należności z tytułu składek ubezpieczeniowych. Oceniając istnienie lub nieistnienie przesłanki ustawowej, a także uwzględniając kryteria dodatkowe, np. możliwości płatnicze wnioskodawcy oraz stan finansów sektora ubezpieczeń społecznych, organ orzekający wybiera konsekwencje prawne swoich ustaleń. Wybór taki nie może być dowolny i musi wynikać z wszechstronnego oraz dogłębnego rozważenia wszystkich okoliczności faktycznych sprawy, a w szczególności tych podnoszonych przez stronę w składanym wniosku o umorzenie należności.

$\mathrm{Z}$ omawianej formy ulgi w zapłacie składek ubezpieczeniowych organy ubezpieczeniowe powinny nie tylko korzystać ze szczególną uwagą skierowaną na bieżący stan finansów sektora ubezpieczeń społecznych, ale również powinny dostrzegać zagrożenia dla równowagi finansowej tego sektora w bliższej oraz dalszej przyszłości (np. spowodowane niekorzystną sytuacją demograficzną ${ }^{53}$, emigracją zarobkową lub rozwojem tzw. szarej strefy na krajowym rynku pracy). Umorzenie powinno pozostawać nadzwyczajnym sposobem wygaśnięcia zobowiązania do zapłaty składek ubezpieczeniowych, stosowanym w ostatniej kolejności, tj. po wyczerpaniu możliwości płynących z zastosowania innych ulg w zapłacie (rozłożenia płatności na raty lub odroczenia terminu zapłaty). Umorzenie należności jest bowiem nieefektywnym sposobem wygaśnięcia zobowiązania. Powoduje zwolnienie zobowiązanego $\mathrm{z}$ obowiązku zapłaty i nie

53 L. Antkowiak, Demografia wymusza zmiany na rynku pracy, „Ubezpieczenia Społeczne” 2011, nr 4, s. 10. 
prowadzi do ograniczenia jego uprawnień do przyszłych świadczeń finansowanych z zasobów funduszy ubezpieczeniowych. W tym kontekście można uznać, że prowadzi do naruszenia interesów pozostałych ubezpieczonych, którzy regularnie oraz w pełnej wysokości opłacają składki na swoje ubezpieczenie społeczne, a więc w części finansują świadczenia tych, wobec których zastosowano umorzenie należności z tytułu składek.

\section{Bibliografia:}

Antkowiak L., Demografia wymusza zmiany na rynku pracy, „Ubezpieczenia Społeczne” 2011, nr 4 s. 9-13.

Bartoszewicz M., Zakolska J., Glosa do wyroku SO we Wrocławiu z 20.05.2003 r., IV Ka 893/02, „Przegląd Legislacyjny” 2003, nr 5, s. 115-120.

Bień-Kacała A., Daniny publiczne. Próba rekonstrukcji pojęcia na tle postanowień Konstytucji RP z 1997 r., „Prawo i Administracja” 2003, t. 2, s. 99-112.

Bień-Kacała A., O definiowaniu danin publicznych raz jeszcze. Uwagi na tle wyroku Trybunału Konstytucyjnego z 19 lipca 2011 r. (P 9/09), [w:] R.M. Czarny, K. Spryszak (red.), Państwo i prawo wobec współczesnych wyzwań, t. 3. Zagadnienia prawa konstytucyjnego. Księga jubileuszowa Profesora Jerzego Jaskierni, Wydawnictwo A. Marszałek, Toruń 2012, s. 517-529.

Jonik A., Umorzenie należności z tytułu składek na ubezpieczenie społeczne rolników w świetle kodeksu postępowania administracyjnego, „Ubezpieczenia w Rolnictwie” 2007, nr 30, s. 32-41.

Koperkiewicz-Mordel K., Stanowienie przez rady gmin zwolnień i ulg podatkowych $w$ podatkach i opłatach lokalnych, „Finanse Komunalne” 2005, nr 1-2, s. 58-74.

Krzywoń A., Podatki i inne daniny publiczne - podstawowe pojęcia konstytucyjne, „Zeszyty Naukowe Sądownictwa Administracyjnego” 2011, nr 2, s. 47-58.

Ruśkowski E., Salachna J.M. (red.), Finanse publiczne. Komentarz praktyczny, ODDK, Gdańsk 2013.

Wantoch-Rekowski J., Umarzanie należności z tytułu składek na ubezpieczenia społeczne, „Praca i Zabezpieczenie Społeczne” 2004, nr 3, s. 33-42. 